\title{
An interpretation of the statutory term "worker": a comment
}

\section{Introduction}

The term "worker" appeared in a number of past and present New Zealand statutes, most importantly the Labour Relations Act 1987. Section 2(1) defined a "worker" as:

(a) Means any person of any age employed by an employer to do any work for hire or reward; and

(b) Includes-

(i) A homeworker; or

(ii) A person intending to work.

The core section $2(1)(a)$, is similar to that used in the statutes which preceded the Labour Relations Act. Over the years this core has been interpreted as meaning a person employed under a contract of service. This interpretation has met with general approval until a recent article by Adzoxornu (1990). Adzoxornu puts forward the intriguing thesis that the correct interpretation is that a worker is any person employed under either a contract of service ("employee") or a contract for services ("independent contractor").

This writer disagrees with Adzoxornu's interpretation of the term and will argue later in this paper that the usual interpretation is in fact clearly superior to Adzoxornu's alternative. However, Adzoxornu has not simply put up an alternative interpretation and claimed it is superior. He has gone much further and put forward arguments about the intent of Parliament over the years, the competence of industrial tribunals, and the function of these tribunals. While the credibility of these further arguments depends on the accuracy of Adzoxornu's alternative interpretation, they merit consideration. This commentary will examine the supplementary arguments, then address the interpretation.

\section{Parliamentary intent}

Adzoxornu claims that right from last century, whenever Parliament has used the term "worker" it has deliberately intended the term to be interpreted as covering those under a contract of service and those under a contract for services: "... whenever Parliament has chosen the term "worker" as opposed to the term 'employee', it has defined the former broadly to include a limitless category of working people" (p.63). Ignoring the fact that in popular usage "worker" and "employee" are regarded as largely synonymous, (The Concise Oxford Dictionary defines "worker" as: "employee, especially in manual or industrial work"). Adzoxornu suggests Parliament has consciously differentiated between the 2, claiming: "It cannot be argued that Parliament lacked the sophistication to distinguish between the 2 terms" (p.65) and: "whenever statute used the

* Department of Management, University of Otago. This comment and Adzoxornu's response were written prior to the repeal of the Labour Relations Act. 
term 'employee', as opposed to 'worker', it has defined the former in terms of a contract of service" (p.64).

This writer considers that it is certainly arguable whether Parliament is sufficiently sophisticated as to make a subtle differentiation between the 2 words The Concise Oxford Dictionary deems synonymous. For example, it has been pointed out (Geare, 1982) that when the grievance procedure was introduced in 1970, Parliament demonstrated it was not sophisticated enough to differentiate between the words "wrongful" and "unjustifiable", and used the former when it meant the latter. The wording had to be changed in a later statute. Indeed, it could well be argued that the usual situation of statute rapidly followed by amendments, argues strongly against sophistication and drafting expertise.

It is also quite possible that Parliament considers worker and employee as interchangeable. Adzoxomu cites the use of "employee" only in 2 fairly recent statutes the Accident Compensation Act 1982 and the Equal Pay Act 1972. Adzoxornu (p.66) gives only part of the definition of "employee" in the Equal Pay Act 1972 as: "[A]ny person who has entered into or works under a contract of service or apprenticeship with an employer, whether by way of manual labour, clerical work, or any other work or effort whatsoever...." Very significantly, Adzoxornu omits the next part of the definition which states an "employee" is: "... any person who is a worker within the extended meaning given to the term 'worker' by subsections (2) and 3) of section 2 of the Industrial Relations Act 1973;..." This clearly refutes Adzoxornu's assertion that Parliament intends "employee" to mean contract of service alone and "worker" to mean contract of and contract for, since they define "employee" as including "worker".

Adzoxornu argues further that with respect to the statutes that preceded the Labour Relations Act:

\begin{abstract}
The law-makers were not interested in the question of whether a person works or intends to work as a "servant" or an independent contractor. Rather the interest was in the person as a potential participant in industrial conflict. Insofar as the person's work or intended work, makes him or her a potential industrial disputant, he or she will become subjected to the control of a trade union; the latter will then define and protect his or her interests (p.73).
\end{abstract}

That is, because Parliament did not want industrial conflict and because independent contractors could cause industrial conflict, Adzoxornu wants us to believe that Parliament considered "workers" to be independent contracts. One could point out that while independent contractors have been known on rare occasions to strike (Bray, 1984) it is incredible to suggest that the fear of independent contractors striking has influenced statute makers.

Possibly the most obvious refutation of this claim that Parliament has intended all along for "worker" to include independent contract, is the fact that Parliament has had ample opportunity over the years to make their intent explicit. Adzoxornu himself points out (p.63) that in one statute, the Bushworkers Act 1945, "bushworkers" are explicitly defined as contractors and employees. So, why did Parliament not simply define "worker" as "employee or independent contractor"? It is stretching one's credibility beyond breaking point to assume that Parliament has endured misinterpretation for nearly 100 years without simply amending the legislation. Thus this claim by Adzoxomu appears unsustainable.

\title{
3. Industrial tribunals
}

Adzoxornu clearly disagrees with the interpretation made by industrial tribunals over the years: "... there is nothing in the Labour Relations Act in particular to justify the 
narrower construction which New Zealand industrial tribunals have placed on the term" (p.67). This is not all however:

It is surprising to see how quickly our industrial tribunals' acceptance of tried and trusted canons of statutory interpretation evaporate into thin air when they are called upon to interpret the statutory term "worker" (p.62)... [They] have limited the construction of the term to a person who works or worked under a contract of service. This is contrary to the elementary and fundamental rule of statutory construction that words in a statute should be given their ordinary meaning unless the result would lead to absurdity, irrationality, hardship, injustice, inconsistency, etc (p.61).

This clearly suggests long standing incompetence, or indeed possibly something more sinister. This is certainly implied when he states:

In spite of the liberal definitions of the term "worker", the Labour Court and its predecessors have decided for reasons which are by no means clear, to limit the meaning of the term to the common law understanding of "servant" or "employee" (p.61).

Thus when combined with Adzoxornu's first claim we see a scenario of Parliament's deliberate intent over the century being deliberately thwarted by industrial tribunals with a hidden agenda. (An alternative is that the tribunals' interpretation is correct.)

\section{Role of unions}

The final argument to be considered is a somewhat peripheral one, which is that Adzoxornu believes that unions should define and determine who is a "worker" for the purposes of the Labour Relations Act. He states: "It is not the province of the Court to make or unmake a "worker" for the purposes of the Act. It must be re-emphasized that this competence is the property of unions" (p.76). He would be correct if Parliament chose to define "worker" as "anyone covered by a union's membership clause". Since it has not done so, then it is submitted that Adzoxornu's claim is fanciful and that it $i s$ the province of the Court to interpret the statutory definition.

\section{Interpretation}

If the term "worker" was simply that given in section 2(1)(a), ("any person of any age employed by an employer to do any work for hire or reward") and that was interpreted in isolation, it could be argued that Adzoxornu has a case - albeit weak. That part definition does not clearly and unambiguously refer only to persons under a contract of service. Possibly a person under a contract for services could also be included. However, the fact that it refers to a person being "employed" is suggestive of a contract of service only, given that popular usage refers to "engaging" a contractor (see definition of homeworker, below). However, if one was interpreting section 2(1)(a) alone, then previous interpretations by Industrial Tribunals are very relevant. As Adzoxornu has pointed out, they have interpreted the definition as meaning a contract of service alone and so under normal interpretation practice one would assume Parliament intended that interpretation to continue. However, it is submitted that when taken in full, the interpretation is perfectly obvious. Section 2(1)(b) includes "homeworkers". Homeworkers are defined as a person:

...engaged, employed or contracted by any other person (in the course of that other person's trade or business) to do work for that other person in a dwelling 
house (not being work on that dwelling house or on fixtures, fittings or furniture in it); and includes a person who is in substance so engaged, employed, or contracted notwithstanding that the form of the contract between the parties is technically that of vendor and purchaser.

That is, a homeworker can be either a special type of independent contractor or a "worker" (employee).

Clearly, if "worker" included all independent contractors, then it would be ludicrous to expand the definition of "worker" to include a special type of independent contractor. Parliament has clearly decided that some contractors are weak and open to exploitation and would like to include them under the umbrella protection of the Labour Relations Act. Thus the statute states "worker" includes homeworkers. The principle of expressio unius est exclusio alterius - that when a subset of what could be included, is included the rest is explicitly excluded - confirms that other independent contractors are excluded.

\section{Conclusion}

This paper contends that the assertions made in Adzoxornu's paper referring to Parliamentary intent, tribunal incompetence and the role of unions to define statutes are incorrect or fanciful and his interpretation of "worker" is also incorrect with the usual interpretation being accurate. This commentary is not taking a position on whether or not it may be a good thing for the definition of "worker" to be explicitly expanded to include all independent contractors. It is asserting that Pariiament has not intended this in the past and the correct definition of "worker" does not include all independent contractors.

\section{References}

Adzoxornu, I.K. (1990) The "worker", the Labour Court and the common law in New Zealand: a holy trinity? New Zealand journal of industrial relations 15(1):61-78.

Bray, M. (1984) Contract labour and industrial regulation: owner-drivers in the Sydney ready-mixed concrete industry. Journal of industrial relations 26(3):291-314.

Geare, A.J. (1984) General limitations in the "right to fire" in New Zealand. Journal of industrial relations 24(4):517-534. 